the temperature of each room should be controlled from the engineer's room, so as to obviate the necessity of the engineering staff having to enter any 'Iodge' room. The 'lodge' cooms are designed to give a maximum supply of conuitioned fresh air equivalent to 1,750 cub. ft. a head an hour. A refrigerating plant is installed for cooling and removing the moisture from the air when necessary. In winter, hot water is supplied by steam-heated storage calorifiers but in summer, owing to the small demand, an electrical thermal storage system is employed. Steam for all purposes is generated by four steam boilers working at a pressure of $100 \mathrm{lb}$. per sq. in. and capable of evaporating 7,000 lb. of water an hour at $212^{\circ} \mathrm{F}$. Storage for the oil fuel is provided by five cylinders having an aggregate capacity of sixty tons.

\section{Research at the Dove Marine Laboratory, Cullercoats}

THE Report of the Dove Marine Laboratory, Cullercoats, Northumberland, for the year ending June 30, 1932, has recently been published. The research during the year dealt chiefly with herring investigations, work on pollution, eonditioned responses in fishes and hydrographical records. Large numbers of young herrings with three winter rings were present in the East Anglian October shoals. A new year class, that of 1928, has appeared in the winter shoals about the north of Scotland. It was not present in the samples from north-west Ireland. Mr. Storrow's work includes notes on organisms coming with the Atlantic waters during the last few years, the abnormal flow in all probability influencing the herring fishery, especially in the Clyde. His conclusions from the age composition of the Northumberland herring shoals are that the data support the idea of a gradual change in the fishing rather than change due to recent oceanic activity. Prof. Meek's work, with the help of Miss Benton, on Sagitta, shows that Sagitta setosa may be an important indicator of currents. Dr. Bull's researches on fish behaviour have been helped greatly by the erection of a partially sound-insulated and entirely separate building. Conditioning experiments involving the stimulus of small temperature increments and changes of direction of current flow are in progress and positive results have been obtained. In his work on the study of colour vision by the technique of differential inhibition, Dr. Bull has shown that the common shanny, Blennius pholis, has a wide range in wave-length discrimination, being able to distinguish one colour from another in many instances.

\section{Coco-nut Palm Products}

Coco-NuT oil derived from copra is by far the most important ultimate product of the coco-nut palm, and the future prospects of the industry are reviewed in a volume under this title, which appears as the second volume of a "Survey of Oil Seeds and Vegetable Oils" (London: H.M. Stationery Office, 2s. net). Within the last ten years there has been an increase of about thirty per cent in the world acreage under coco-nuts, bringing the total to 7,000,000 acres in 1931. Since 1921 the British Empire has accounted for slightly more than half this amount. The increase in production has been mainly due to the demand from the United States, but the needs of that country can be met by the production from the Philippines. Other producing countries, including those of the British Empire, must be chiefly dependent upon European consumption. Owing to the heavy production of whale oil, however, there is at present no sign of an increased demand in the European market. In this market the demand for coco-nut oil depends upon the expansion of the soap and margarine industries. The survey concludes that the output of copra will be on the increase for several years and that the bulk of this will appear on the world market, although local consumption accounts for a considerable proportion of the output of most producing countries, especially of India, the Dutch East Indies, and the South Sea Islands.

\section{Science Museum Handbook of Pumping Machinery}

THE recently issued handbook to the collection of pumping machinery at the Science Museum (H.M. Stationery Office, 2s. 6d. net) prepared by Mr. G. F. Westcott, should be of widespread interest. It is not a catalogue to the exhibits but a general introduction to the development of pumps illustrated by drawings and photographs of actual plant or models. The ground it covers extends from the earliest baling appliances to the most recent molecular vacuum pumps. After a general review of what may be called the philosophy of pumping, there are four sections dealing in turn with pumps for liquids, pumps for gases, high vacuum pumps and multiple purpose pumps. There are thirty plates in all, including a reproduction of the Museum chart illustrating the development of pumping machinery. This ingeniously worked-out chart might prove useful in many technical schools. One illustration of great historical interest is that of the famous pumping plant erected at Marly by order of Louis XIV for supplying water from the Seine to the fountains at Versailles. With its fourteen waterwheels, its 253 pumps and its connecting mechanism, it was probably the largest machine ever erected. Its effective horse power, however, was very small and it is said that the King of Denmark once remarked to Louis that his water cost him as much as his wine.

\section{Death Valley a new 'National Monument'}

ON February 11, by presidential proclamation, President Hoover gave the status of 'national monument' to Death Valley, famous in the history of California for the hardships endured by pioneer trains crossing its arid, salt-crusted waste (Science Service, Washington, D.C.). A national monument differs from a national park only in respect to grade of protection; administration is simpler, either because of difficulty of access, lack of funds to provide full national park administration, or other reasons. The area of the new monument is $1,601,800$ acres, about two-thirds of the total land in the Valley, and its dryness is so great that mineral salts of several varieties form thick crusts upon the surface of the soil. Of these, the borax deposits used to be 